Available online at http://journal.bajas.edu.iq

Basrah Journal

College of Agriculture, University of Basrah

DOi:10.21276/basjas

of Agricultural

Sciences

ISSN $1814-5868$

Basrah J. Agric. Sci., 32(2): 16-22, 2019

E-ISSN: 2520-0860

\title{
Chemical Indicators of Ostrich Struthio camelus Linnaeus, 1758 Meat Burger Prepared by Adding Different Fat Levels During Frozen Storage
}

\author{
Alaa M.S. Al -Baidhani *\& Aum El-Bashar H.J. Al-Mossawi \\ Department of Food Science, College of Agriculture, University of Basrah, Basrah, Iraq \\ *Corresponding author e-mail: allamo1978@gmail.com \\ Received 15 December 2018; Accepted 15 January 2019; Available online 1 November 2019
}

\begin{abstract}
This study included preparation of ostrich meat burger with different levels of ostrich fat. The first treatment was free-fat and the second treatment $5 \%$ fat, the third treatment was $10 \%$ fat, the fourth and the fifth was $15 \%$ and $20 \%$ respectively and stored in $18 \pm 2 \mathrm{c}^{\circ}$ for 120 days. Changes in chemical indicators were studied including peroxide value (PV), thiobarbituric acid (TBA), free fatty acids (FFA) and total volatile nitrogen (TVN) during storage periods 1, 30, 60, 90 and 120 days. The results showed that there is significantly increased $(\mathrm{P}<0.05)$ in PV, TBA and FFA by increasing the fat levels and the storage periods while TVN decreased by increasing fat levels and increased storage periods.
\end{abstract}

Keywords: Chemical Indicators, Ostrich meat burger, Ostrich fat levels.

\section{Introduction}

Recently, the importance of Ostrich breeding has increased in order to obtain its meat, which began to gain worldwide popularity at the end of the last century. This came after growing interest in breeding poultry such as chickens, ducks, geese, and turkeys. At the same time, consumer confidence has decreased in traditional kinds of meat produced and especially with the use of chemical additives the spread of animal diseases, as well as consumers' search for a healthy diet, have contributed to the development of ostrich farms and the production of ostriches worldwide (Shameeva et al., 2018).
Breeding of ostriches has gained increasing attention due to the qualitative and nutritional qualities of meat in terms of health and nutrition. it is characterized by a low level of fat, cholesterol and its high content of polyunsaturated fatty acid (PUSFA), which contribute to reduce the risk of cardiovascular disease, as well as the production of meat, which exceeds the production of meat from cows, sheep and deer, so ostrich meat is the best in the market and is bred in Australia, Asia, Africa and North, South America successfully to provide the conditions for his education (Cooper \& Horbañczuk, 2002).

Many efforts have been made to improve the quality and stability of burger during 


\section{Al -Baidhani \& Al-Mossawi / Basrah J. Agric. Sci., 32(2): 16-22}

storage it to suit the increasing consumer demand for fast food health in recent years, ostrich meat is regarded as a healthy alternative to other meat for its nutritional content, it also has a high water holding capacity and its distinctive and desirable flavor, as well as its low content of collagen which facilitates the process of cooking (Fernández-López et al., 2006; Zarasvand et al., 2013).

Inasmuch to the content of ostrich meat and fat of food ingredients, including protein, minerals, vitamins and fatty acid (omega-6 and omega-3) and low cholesterol content compared to other meat this characteristic is very important in terms of health, as well as the good functional properties of ostrich meat proteins make it suitable in different manufacturing processes and the lack of a local study on this type of meat, especially that ostrich farming has spread in several provinces in Iraq .The aim of this study was to prepared burger by adding different levels of ostrich fat and evaluation of chemical indicators during frozen storage period (120 days).

\section{Materials \& Methods}

Black neck ostrich bird was bought from the farms of the Babil Governorate in the Mahaweel district, it was slaughtered, feathers removed, meat and fatty tissues were isolated from the rest of the carcass.

\section{Preparation of Ostrich Burger}

Ostrich meat were minced and calculated according to each treatment, first treatment was free-fat, second treatment was added to it $5 \%$ fat, third treatment was added to it $10 \%$ fat, fourth treatment was added to it $15 \%$ fat and the fifth was added to it $20 \%$ fat then added to each treatment $2 \%$ flour, salt $1.5 \%$ and mixture of spices $0.5 \%$. Prepared burger was put in bags of polyethylene vacuum from the air and stored in a freezer for 120 days during these periods chemical indicators were calculated before freezing and after 30, 60, 90 and 120 days, which included peroxide Value (P.V), thiobarbituric acid (TBA), free fatty acids (FFA) and total volatile nitrogen (TVN). Peroxide value was calculated according to Egan et al. (1988), thiobarbituric acid (TBA) follows the method mentioned by Pearson (1970) and contained in the Al-Qutaifi (2019). Free fatty acids and total volatile nitrogen were calculated according to (Al-Tai \& AlMossawi,1992).

Factorial Experiment Designing (CRD) was used to analyze all the studied factors and was statistically analyzed by the SPSS (2016). These factors were tested using a least significant difference (R.L.S.D) at a probability level of (0.05).

\section{Results \& Discussion}

\section{Peroxide Value (PV)}

Results in fig. (1) demonstrated that there was significant increase $(\mathrm{P}<0.05)$ in the peroxide values by increase fat levels and storage periods, peroxide values were $0.39,0.42$, $0.43,0.45$ and 0.53 meq. $\mathrm{kg}^{-1}$ for $0,5,10,15$ and $20 \%$ respectively, these values were noted convergent that before storage as there were no obvious differences between treatments while during the storage period, the differences were clear, after 30 days of storage, they reached $0.59,0.87,1.16,1.33$ and 1.82 meq. $\mathrm{kg}^{-1}$ respectively. The increase in peroxide values continued to the end of storage period which reached to $1.7,2.23$, $3.01,3.22$ and 3.51 meq. $\mathrm{kg}^{-1}$ respectively. The reason for the high peroxide values in the burger, during storage due to oxidation of fat which contains high polyunsaturated fatty acid and therefore these acids are quickly oxidized during storage, resulting many compounds, including peroxides, aldehydes 


\section{Al -Baidhani \& Al-Mossawi / Basrah J. Agric. Sci., 32(2): 16-22}

and ketones, which gives smell and flavor undesirable. This is agreed with Alali (2018) who reported that the production of low-fat beef burger with fat percentages of $0 \%, 5 \%$,
$10 \%, 15 \%$ and $20 \%$ as peroxide values increased by increasing the percentage of fat and the continuation of the storage period freezing.

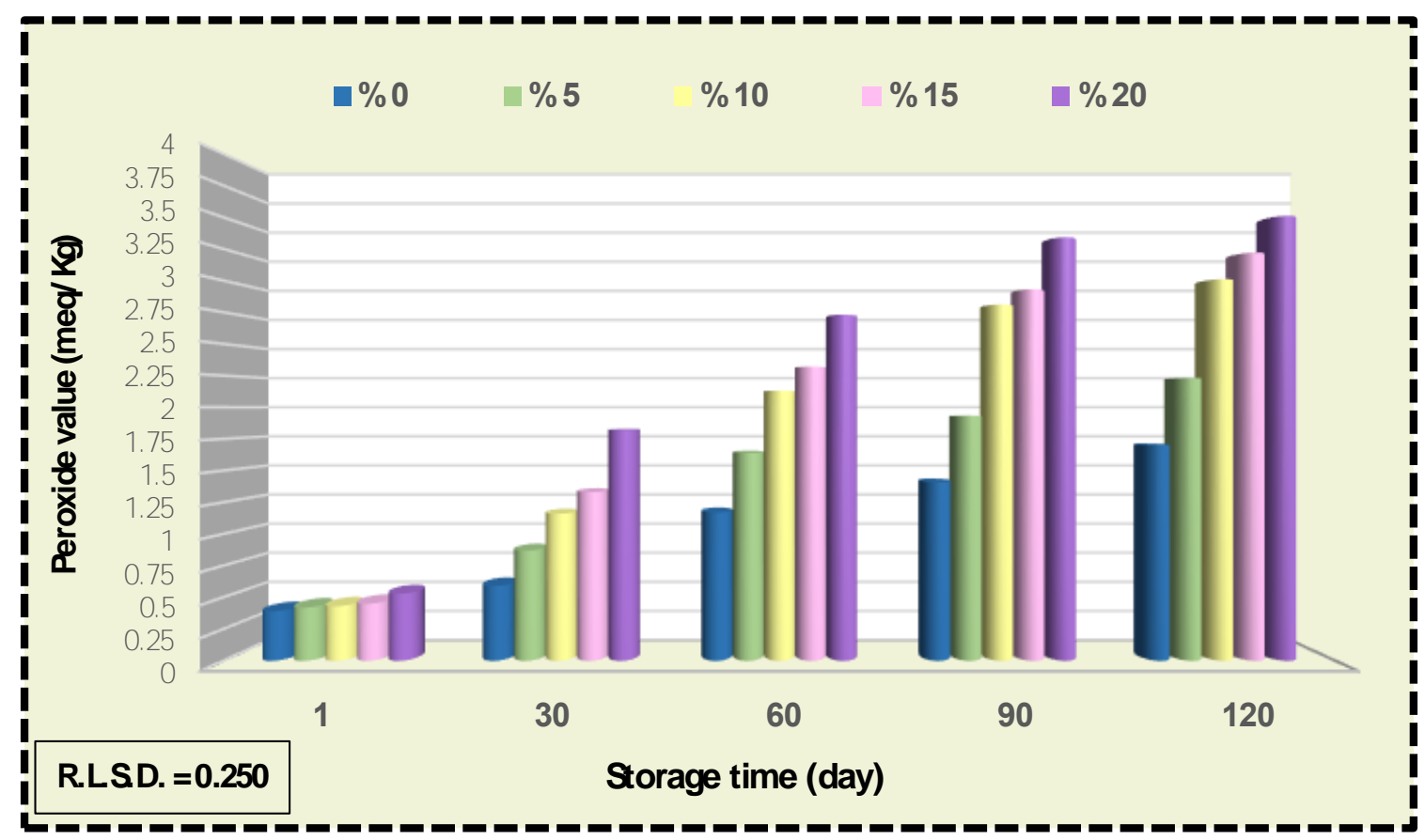

Fig. (1): Effect of fat levels and freeze period on the peroxide value of Ostrich burger

\section{Thiobarbituric Acid (TBA)}

The results in fig. (2) explained the effect of fat levels and storage period on the value of thiobarbituric acid in ostrich meat burger. The results showed that them were significant differences $(\mathrm{P}<0.05)$ in TBA values according of the acid in burger prior to storage was $0.39,0.42,0.43,0.45$ and 0.53 mgMDA. $\mathrm{kg}^{-1}$ for added fat levels $5 \%, 10 \%$, $15 \%$ and $20 \%$ respectively. The storage period significantly affected $(\mathrm{P}<0.05)$ on the acid value, TBA increased continuously after 30 days reaching $0.41,0.71,0.91,1.11$, and 1.57 mgMDA. $\mathrm{kg}^{-1}$ at the addition of $0 \%, 5 \%$, $10 \%, 15 \%$ and $20 \%$ fat respectively, after 90

days of storage, acid values increased to 1.2 , $1.63,2.14,2.66$, and 3.15 mgMDA. $\mathrm{kg}^{-1}$ respectively. These values continued to rise after 120 days of storage to $1.92,2.32,2.68$, 3.13 and $3.68 \mathrm{mg}$ MDA. $\mathrm{kg}^{-1}$ respectively.
The results showed that the value of acid increased by increasing the levels of fat by progressing the storage time. This was confirmed by Soyer \& Ertas (2007) in the study of the production of beef sausage and the addition of fat at different rates of $10 \%$, $20 \%$ and $30 \%$ and storage of refrigeration for 60 days, the value of TBA gradually increased with the increase in the added fat and the duration of the storage was at $30 \%$ fat is the highest compared to the rest of the proportion for the acquisition of oxidation of fat during storage, resulting in peroxides, aldehydes and ketones. The results were agreed with Gómez \& Lorenzo (2013) when they were prepared with different fat percentages of $10 \%, 20 \%$ and $30 \%$. TBA values increased with increasing fat levels and storage time, the increase was more pronounced at $30 \%$. 


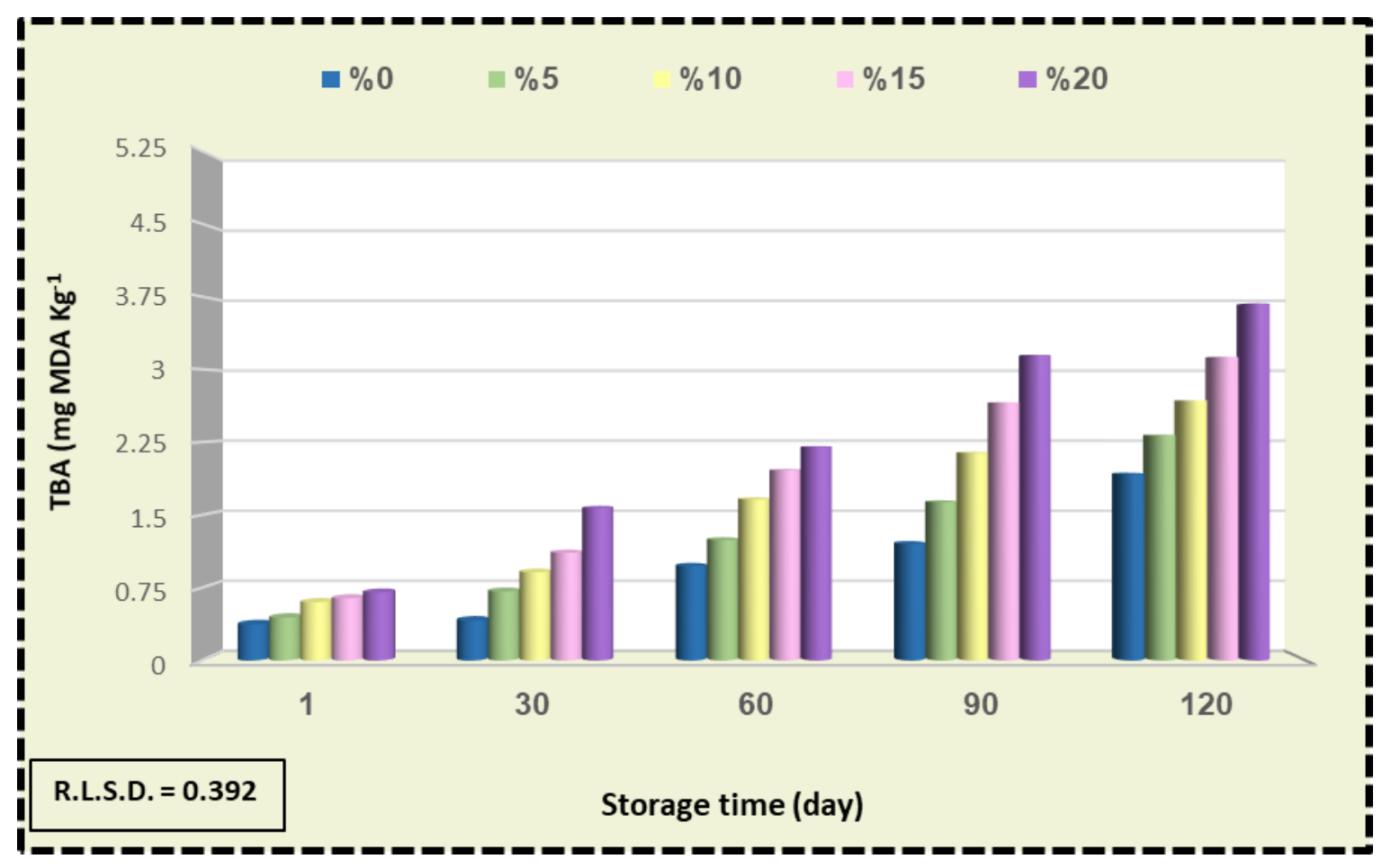

Fig. (2): Effect of fat levels and freeze period on the thiobarbituric acid of Ostrich burger.

\section{Free Fatty Acids (FFA)}

The results in fig. (3) indicated that the percentage of free fatty acids in ostrich meat burger The results of the statistical analysis showed that the increase in the percentage of fat added significantly $(\mathrm{P}<0.05)$ on the percentage of free fatty acids in the berker tablets as the percentage of free fatty acids increased with the added fat increased with fat levels. FFA in burger free-fat was $0.48 \%$ at the addition of $5 \%$ fat was $0.51 \%$ and $0.56 \%$ at added $10 \%$ fat, the addition of $15 \%$ fat was $0.57 \%$. fat by $20 \%$ was $0.59 \%$.

The results also showed that the progress of storage periods was significantly affected by FFA ( $\mathrm{P}<0.05)$. The results showed that FFA percentage increased after 30 days of frozen storage reached $0.57 \%, 0.63 \%, 0.74 \%, 0.99 \%$ and $1.20 \%$ in burger free-fat and added patties $5 \%, 10 \%, 15 \%$ and $20 \%$ fat respectively, this increase in FFA continued at the end of the 120 -day storage period and reached to $1.16 \%$, $1.57 \%, \quad 1.80 \%, \quad 2.05 \%$ and $2.21 \%$ respectively. The results indicate an increase in the value of FFA when fat is increased and the period of freezing is due to the activity of lipase enzyme, which analyzes triglycerides as free fatty acids are the products of the processes of hydrolysis of lipids by lipase enzyme. The results agreed with Soyer \& Ertas (2007) who reported that the addition of fat at different levels of 10\%, 20\% and 30\% to beef sausage increased in FFA by increasing the fat levels and during storage periods. 
Al -Baidhani \& Al-Mossawi / Basrah J. Agric. Sci., 32(2): 16-22

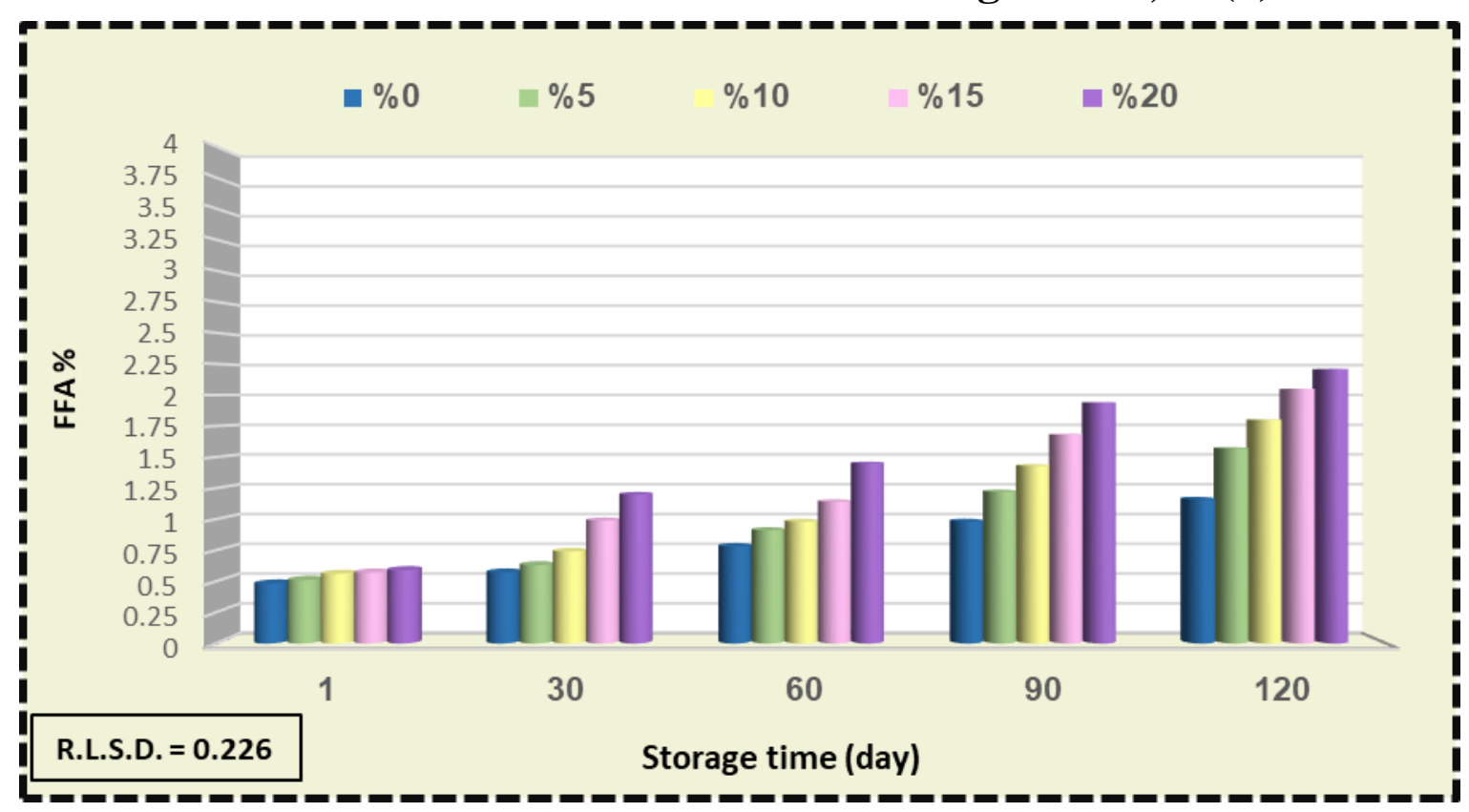

Fig. (3): Effect of fat levels and freeze period on Free Fatty Acids of Ostrich burger.

\section{Total Volatile Nitrogen (TVN)}

The results in fig. (4) exhibited that the added fat percentage of the ostrich meat burger significantly affected $(\mathrm{P}<0.05)$ on the values of total nitrogen volatile as it reached before storage $1.08 \mathrm{mg} \mathrm{N} .100 \mathrm{~g}^{-1}$ in the burger freefat, while $1.04 \mathrm{mg} \mathrm{N} .100 \mathrm{~g}^{-1}$ at $5 \%$ fat and

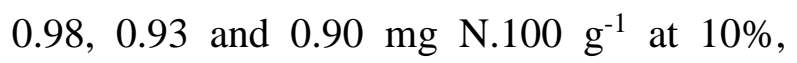
$15 \%$ and $20 \%$ respectively. The decrease in the total nitrogen content of the meat burger may be due to the decrease in the protein content in the patties by increasing the fat levels and the volatile nitrogen content is dependent on protein hydrolysis processes, a decrease that led to a decrease in the TVN values.

The results showed significant increase $(\mathrm{P}$ $<0.05)$ in the TVN values during the storage period. The values were increased in all treatments, but the height was more pronounced in the burger free-fat, the TVN value increased from $1.08 \mathrm{mgN} .100 \mathrm{~g}^{-1}$ before storage to $2.36 \mathrm{mgN} .100 \mathrm{~g}^{-1}$ after 30 days and then to 2.66 and $3.97 \mathrm{mg} \mathrm{N} 100 \mathrm{~g}^{-1}$ after 60 and 90 days respectively and continued to rise to $5.83 \mathrm{mg} \mathrm{N} .100 \mathrm{~g}^{-1}$ at the end of the storage period thus, for all treatments TVN increased after 60 days to $2.31,2.07,1.96$, and $1.83 \mathrm{mg}$ N.100 $\mathrm{g}^{-1}$ for $5 \%, 10 \%, 15 \%$ and $20 \%$ fat levels respectively, continued to rise gradually and clearly until the end of the storage period of 120 days to 5.78 and 5.63 and 5.47 and $5.35 \mathrm{mg} \mathrm{N} / 100 \mathrm{~g}$ for fat levels respectively. This increase values of TVNB continuously in the freezing period may be due to protein hydrolysis processes by the enzymes and the microbial and the production of total nitrogen volatile compounds and the process of defrosting the patties increase the height ratios, and this is confirmed by Darwish et al. (2011) in their study when prepared beef burger and store it for 3 months for periods $0,2,4,6,8,10$ and 12 weeks. As Ibrahim et al. (2018) in his study showed that the values of TVNB increased during the period of storage for 15 days in refrigeration. 
Al -Baidhani \& Al-Mossawi / Basrah J. Agric. Sci., 32(2): 16-22

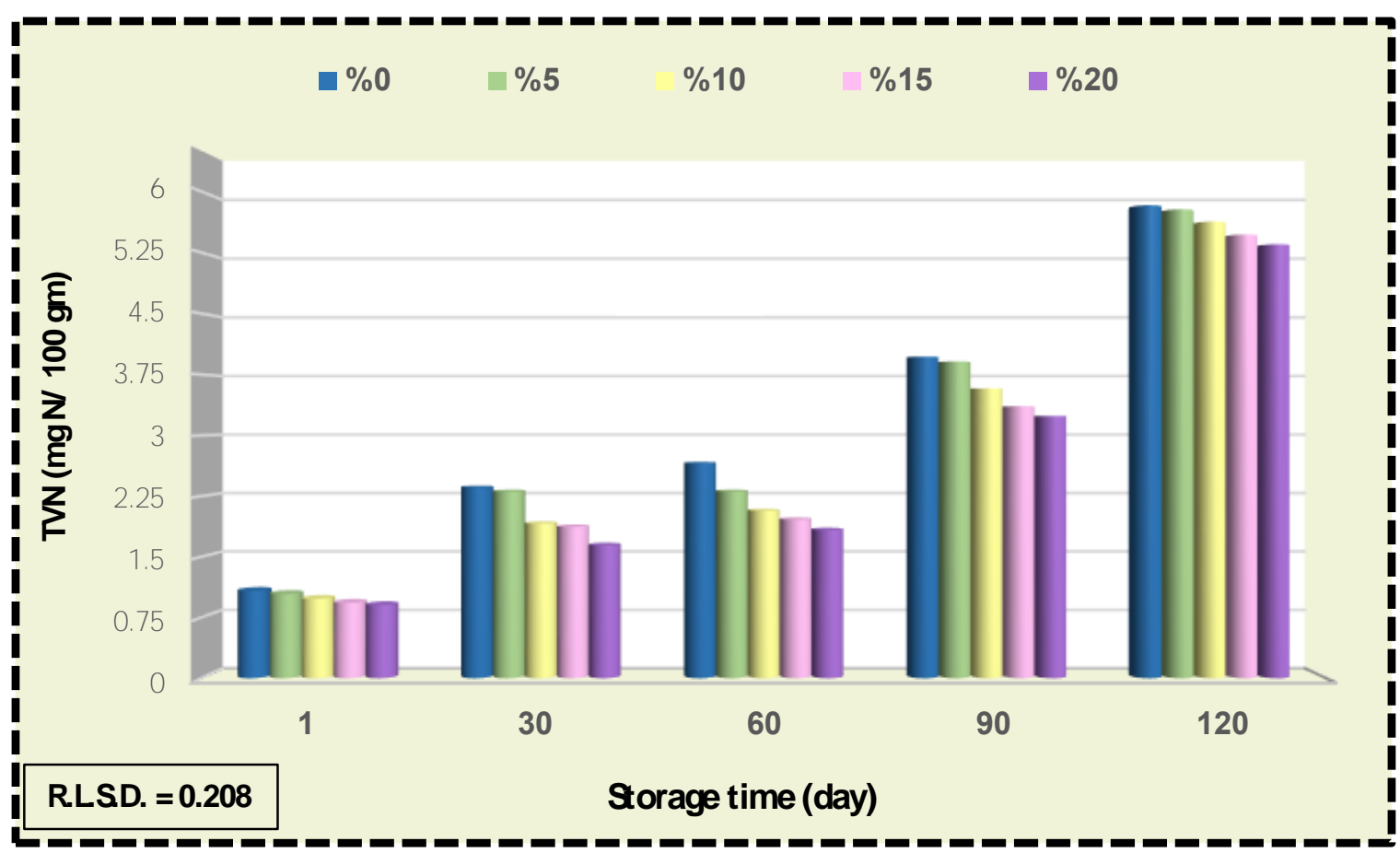

Fig. (4): Effect of fat levels and freeze period on Total Volatile Nitrogen of Ostrich burger.

\section{Conclusions}

The effect of the different levels of fat added to the ostrich meat burger on the values of the chemical indicators for the length of the storage period in freezing, as it was found that the burger added fat percentage of $15 \%$ and $20 \%$ have a clear effect on chemical indicators, while fat percentage $5 \%$ and $10 \%$ fat and free-fat patties have less impact on those indicators.

\section{Acknowledgments}

The authors would like to thank the Department of Food Science, College of Agriculture, University of Basrah for all facilities and equipment provided.

\section{Conflicts of interest}

The authors declare that they have no conflict of interests.

Ethical approval: all applicable national and international guidelines for the care and use of animals were followed.

Alaa M.S. Al -Baidhani: ORCID:0000-

0002-1539-1409.
Aum El-Bashar H.J. Al-Mossawi: :

ORCID:0000-0001-5096-4164.

\section{References}

Alali, F.R.M. (2018). Preparation of low fat beef burger and study It's quality properties during frozen storage. M. Sc. Thesis, Coll. Agric., Univ. Basrah: 92pp.

Al-Qutaifi, H.K.H. (2019). Identification of active compounds in onion, potato and limon peels and study the efficiency on preservative of quality properties of beef patties during refrigeration and frozen storage. M. Sc. Thesis, Coll. Agric., Univ. Basrah: 134pp.

Al-Tai, M.A. \& Al-Mossawi, U.B.H. (1992). Practical Technology of Meat and Fish. Coll. Agric., Univ. Basrah Press.: 142pp.

Cooper, R.G. \& Horbańczuk, J.O. (2002). Anatomical and physiological characteristics of ostrich (Struthio camelus var. domesticus) meat determine its nutritional importance for man. Review article. Anim. Sci. J., 73(3): 167-173.

Darwish, A.M.; Ibrahim, A.M.; Osama A.; Ataala, O.A. \& Abdelsalam, A.A. (2011). 


\section{Al -Baidhani \& Al-Mossawi / Basrah J. Agric. Sci., 32(2): 16-22}

Effect of some nutritional additives on the quality and formulation cost of beef burger. World J. Dairy Food Sci., 6(2): 180-188.

Egan, H.; Kirk, R.S. \& Sawyer, R. (1988). Pearson's Chemical Analysis of Food. Logman Scientific and Technical. The Bathpress. Avon. $8^{\text {th }}$ ed., New York. 591pp.

Fernández-López, J.; Yelo, A.; SayasBarberá; E.; Sendra, E.; Navarro, C. \& Pérez-Alvarez, J.A. (2006). Shelf life of Ostrich (Struthio camelus) liver stored under different packaging conditions. J. Food Prot., 69(8): 1920-1927.

Gómez, M. \& Lorenzo, J.M. (2013). Effect of fat level on physicochemical, volatile compounds and sensory characteristics of dry-ripened "chorizo" from Celta pig breed. Meat Sci., 95(3): 658-666.

Ibrahim, H.M.; Hassan, I.M. \& Hamed, A.A.M. (2018). Application of Lemon and Orange Peels in Meat Products: Quality and Safety. Int. J. Curr. Microbiol. App. Sci., 7(4): 2703-2723.

Pearson, D. (1970). The chemical analysis of food. chemical publishing company, INC. New York: 604pp.
Shameeva, U.; Sobiech, P.; Zhanabekova, G.; Zhumageldiev, A.; Ussenbayev, A.; Khusainov, D.; Wysocka, D.; Anna Snarska, A. \& Samardžija, M. (2018). The influence of different concentrations of feed additive, based on shell rock and bentonite, on the growth, blood and meat parameters of the African black ostrich (Struthio camelus) in south-east Kazakhstan. Vet. Arhiv., 88(3): 413-425.

Soyer, A. \& Ertas, A.H. (2007). Effects of fat level and storage time on lipid and color stability of naturally fermented Turkish sausages (SUCUK). J. Muscle Foods. 18(3): 330-340.

SPSS (2016). Statistical package for social science, version 24. Users guide for statistical, Chicago.

Zarasvand, S.A.; Shekarforoush, S.S.; Aminlari, M.; Kadivar, M. \& Eskandari, M.H. (2013). Comparison of physicochemical and sensory properties of emulsion-type sausages made with ostrich, beef and turkey meats. Adv. Food Sci., 35(4): 190-195. 